\title{
An Amateur's Raid in a World of Specialists? The Swedish Essay in Contemporary Public Debate
}

\author{
By Emma Eldelin
}

\begin{abstract}
The point of departure of this paper is a lecture by Edward Said, in which he claimed it necessary for today's intellectuals to respond to modern specialization by assuming an attitude of amateurism in public life. It can be argued that there is a historical connection between the public role of the learned amateur and the essay as a form of expression and communication. Among recent advocates of the essay, the decline of this genre in modernity has sometimes been explained by the increasing public confidence in experts and specialists. According to this view, the development of modern society has made it less legitimate for essayists to serve as generalist commentators on society and culture. However, the growing tension between amateurism and professionalism goes back at least to the nineteenth century, and it has marked the ambiguous relation of the essay and the essayist to academia and institutional discourse ever since.

This paper discusses what has become of this public role of essayists in late modernity. Some examples of essayists and essayistic writing of later decades, chiefly from Sweden, serve as illustrations of a general line of argument, even though there are also comparisons between the essay in Sweden and in other countries. Among the examples of Swedish essayists put forward here are Kerstin Ekman and Peter Nilson. The reception of these writers suggests that the essayist, adopting the role as amateur, driven by devotion and interest for the larger picture, might still be a vital part of public culture today. However, it is also clear that writers like Ekman and Nilson have gained at least part of their authority from being acknowledged in other fields or genres - Ekman as a distinguished novelist and Nilson as a trained astronomer.
\end{abstract}

Keywords: Swedish essay, late modernity, amateur, authority in literature, persona, Kerstin Ekman, Peter Nilson 


\section{Introduction}

In 1993, the literary theorist Edward Said gave the Reith Lectures on the subject The Representations of the Intellectual (Said 1994). In these lectures, broadcast on BBC Radio 4, he discarded several of the explanatory factors given by recent debaters, among them John Carey (1992) and Russell Jacoby (1987), for the decline of intellectuals in contemporary public debate. Instead of blaming the postwar explosion of higher education, the universities monopolizing intellectual work, or the increasing commercialization of journalism and publishing, Said asserted that the largest threat to intellectual life in contemporary society was an attitude of professionalism. By professionalism, he meant

\section{[...] thinking of your work as an intellectual as something you do for a living, between the hours of nine and five with one eye on the clock, and another cocked at what is considererd to be proper, professional behavior - not rocking the boat, not straying outside the accepted paradigms or limits, making yourself marketable and above all presentable, hence uncontroversial and unpolitical and 'objective' (Said 1994: 55).}

In contemporary society, Said argued, the true intellectual was often expected to be a specialist or professional in a certain discipline or field. There was not only an increasing expectancy of specialization in higher levels of the educational system, but also a widespread cult of expertise and expert authority in society at large. In a system that rewarded conformity, the most pressing task for the intellectual should therefore be to respond to modern professionalization by representing a different set of values and ideals. He or she should assume an attitude of amateurism, which Said described as

\section{[...] the desire to be moved not by profit or reward but by love for and unquenchable interest in the larger picture, in making connections across lines and barriers, in refusing to be tied down to a specialty, in caring for ideas and values despite the restrictions of a profession (ibid.: 57).}

Even though Said does not elaborate on his definition of amateurism in the lectures, he seems to refer to the etymological roots of Latin amatorem, which means "lover of" (Stebbins 1992: 43). Amateurism might then aim at something you do primarily out of devotion and commitment. Even though there might be other, more sociological definitions of the amateur (cf. ibid.), for Said, it rather seems to be a question of attitude, of spirit, of a way of acting and behaving in public life.

The role of the amateur or generalist in contemporary public debate, stressed by Said and in focus of attention in this paper, is evidently not a new one. During the eighteenth and nineteenth centuries, it was quite common for writers and thinkers to adopt this role, not least while using the essay as a means of expression and communication. Essayists of the past often spoke and wrote as nonspecialists, but still, "they knew how to speak with a generalist's easy authority”, claims Phillip 
Lopate (2007: 390), an American author and essayist, in discussing why this typical persona or public role of essayist writers is no longer very frequent. The essayist, considered as a man of letters (the major part of essayists until the early twentieth century were male, cf. Boetcher Joeres \& Mittman 1993), used to speak comfortably of just about everything, serving as a commentator on society and culture, on manners and customs in the periodicals of the day. In public life, these men of letters were often looked upon as providers of moral and intellectual guidance (Gross 1969).

The role as generalist or amateur was often made legitimate through the essayist's habit of quotation. Just as Montaigne abundantly quoted his ancestors from classical antiquity (expecting his reader to recognize the sources), essayists, at least until the twentieth century, often addressed themselves to an educated reader, assuming that they shared with their public an idea of a universal literary culture. "Though the early essayists' habit of quotation may seem excessive to a modern taste, it was this display of learning that linked them to their educated reading public and ultimately gave them the authority to speak so personally about themselves”, writes Lopate (2007: 387). Even though such a literary culture possibly existed only as an ideal for a very limited group of readers and authors perhaps consistent with what Jürgen Habermas (1962/1989) has spoken of as the "public sphere" - it had an imaginative power, and as such it was often used by essayists as a pretext for speaking about anything and everything.

Both Said and Lopate seem to point to the generalist or amateur as a legitimate and even indispensable public role in contemporary society as well. While Said does not explicitly discuss the verbal forms suitable for expressing such a generalistic attitude, for Lopate, it seems that the essay has for a long time been the congenial genre for the discourse of the amateur. However, compared to the confident guides of the eighteenth or nineteenth centuries, the essayists of later decades have had problems with their authority. In a multicultural world, where the idea of a universal literary culture might seem dated, conservative as well as attached to a particular social group, essayists have often replaced references to literary learning with more personal experience. According to Lopate (2007: 388), this tendency might often be hazardous, as it is risky to suppose that "individual experience alone can constitute the universal text that all may dip into with enlightenment”.

Evidently, Lopate's main concern is the state of the essay in American culture during the last few decades. Just like Said, he is troubled by the increasing public confidence in experts and specialists, as it might have made the essayists' fondness for making general comments on societal and cultural matters even less legitimate. He claims that scientists like Stephen Jay Gould and Oliver Sacks have attracted attention as essayists at least partly because they have been perceived as experts; their readers "are reassured they are 'learning' something, not just wasting their time on belles lettres" (ibid.: 390). If Lopate's observation is correct, 
what reason should people then have to listen to the essayist who might not be addressing the public as a surgeon, a biologist, a physicist or a literary theorist? On what grounds is the essayist - as an amateur - authorized to speak, and what are the certain attractions of the essay, as method and form of expression, in a world of specialization? How is the essayist, enacting the role as learned amateur, perceived in public debate today? Below, I will touch on these issues by means of some examples, chiefly from another national and cultural context - Sweden thereby also making some brief comments on the state of the essay and essayistic writing in contemporary Swedish culture, as viewed in a wider context. However, I will start by again referring to Lopate, as one of his essayistic books bears many similarities to the Swedish examples presented here.

\section{A Form to Encompass All?}

Despite being doubtful about the impact of today's essayists speaking as learned amateurs, Lopate himself deliberately adopted this very persona in Waterfront (2004), a book that might be described as an essayistic walk around the Manhattan shoreline, scattered with references to technical facts, autobiographical fragments, and fiction. In an interview about writing the book, Lopate admitted he was sometimes bothered that readers perceived him as a specialist who knew all about waterfront history, asking him obscure questions he could not answer, since he had studied the subject just enough to "tell the story". In comparing himself as an essayist and writer with the historian, he claims that the latter would have said "I still need another few years to read all the documents"”, while this was never Lopate's intention (Taylor 2006: 133f). He wanted to enact the role of generalist or man of letters, because it allowed him to be personal, and to combine a wide range of material and methods without being exhaustive or systematic. This role is further emphasized by the fact that Waterfront was originally supposed to be published in a series of "belletristic guidebooks"; it was a book that an editor asked Lopate to write, but which he hesitated about, partly because he did not at first find the accurate form for it (ibid.: 126). Eventually, Waterfront did not turn out the type of guidebook it was originally meant to be, but something much more wide ranging: an “'everything but the kitchen sink' book”, as Lopate calls it (ibid.: 134). He searched for a form where he could purposely work with discordant materials. Making use of his experience of essay writing obviously made this possible, as he describes the book as "an anthology of essay types" and overall stresses the affinities with the essay tradition (ibid.: 131).

True enough, the book-length, all-encompassing Waterfront might perhaps not be apprehended as an essay in the traditional sense (a commonplace definition of the essay being “a short, non-fictional prose form”, Obaldia 1995: 11). Among the typically external and formal aspects of essay definitions is the question of length. As Peter France (2005: 25) has pointed out, there are major differences between 
English and French usage in this regard. It is in the English-speaking world, predominantly, that the essay has been viewed as a relatively short prose form, while the French essai has for a long time referred to all kinds of non-fictional prose, often to books. In part, this difference might be explained by the heavy influence of the periodical press on the Anglo-American essay from the eighteenth century onwards, with its favouring of texts that could be read at one sitting (ibid.: 33). As an example of the Anglo-American view, for some perhaps verging on the comic due to its exactitude, Graham Good (1997: xix) has argued that essays are "texts of between one and about 50 pages". Even though Good has admitted that the term could sometimes be used for book-length works, he is sceptical about whole books being consistent with the ideal of spontaneity so common in the essay tradition (1988: xi). Nevertheless, changes in publishing during later decades might have made it more attractive for essayists to write essayistic books rather than compiling collections of previously published essays, as there are fewer periodicals and magazines today that seem willing to provide the necessary space for essayistic writing (cf. Lopate 2007: 388f).

Apart from length, it is also possible to describe the essay by pointing to some of its inner features - many of them clearly present in Waterfront - among them the typically essayistic approach to a topic which has been described as "provisional and exploratory, rather than systematic and definitive" (Good 1997: xix). Further, the essay has often been viewed as random, fragmentary or sauntering. "Rather than progressing in a linear and planned fashion, the essay develops around a number of topics which offer themselves along the way", writes Claire de Obaldia (1995: 2). The essayist acts as if all subjects are naturally linked to one another, by using association and digression as textual and compositional tools (Lopate 1995: xxvii). There are multiple points of contact among thoughts rather than hierarchy, coordination rather than subordination. Montaigne's essays, for example, were often additive and in lack of clear linear direction (Good 1988: 19f). The effect of this is, in the words of the British writer Aldous Huxley (1960: ix), that the essayist tries "to say everything at once", which is "as near an approach to contrapuntal simultaneity as the nature of literary art will allow of". The essay seems, at least ideally, to be the form to encompass all. One might perhaps even, as Lopate does with Waterfront, describe this kind of writing as striving for an "aesthetic of impurity" (Taylor 2006: 135).

\section{Winding Paths, Dead Ends and Exhaustion - Kerstin Ekman's "Masters of the Forest"}

Turning now to my first Swedish example, there are some apparent similarities between the form and approach of Waterfront and Kerstin Ekman's Herrarna i skogen ("Masters of the Forest", 2007). The latter might be described as a wideranging, essayistic account of the relationship of nature and civilization through 
the lens of the forest, particularly the Nordic and Swedish variety. The book is overflowing with references to reading and thought about the forest, from Virgil to Simon Schama. Already, it has been represented as the first cultural history of the Nordic forest (e.g. Jonsson 2007; Olsson et al. 2009: 527). To descibe the scope of Herrarna i skogen as extravagant or excessive seems not to be entirely inadequate - as several critics have noticed, Ekman seems to have scoured Western literature, art, and science for every possible depiction of the forest, fusing them together in an immense volume of about 550 pages (cf. Jonsson 2007; Lingebrandt 2007).

For non-Swedish readers, Kerstin Ekman might be most well known for her crime story Händelser vid vatten ("Blackwater”, 1993), for which she was awarded the August (Strindberg) prize. In Sweden, she has for a long time been a widely recognized and highly respected writer, praised for novels like the "Katrineholm” series (1974-83), Rövarna i skuleskogen ("The Forest of Hours", 1988) or the trilogy with the overall title Vargskinnet ("The Wolfskin”, 19992003). In many of these novels, the forest and the shifting northern landscapes are ubiquitous. As Anna Paterson (2008a: 41) has noted, Ekman is a writer who has stayed true to her native culture and the national heritage. As an acknowledgement of her literary oeuvre, she was elected member of The Swedish Academy in 1978. Since 1989, however, Ekman has chosen not to take an active part in the Academy, after having accused it of being too indulgent in the debate on the death threats posed to writer Salman Rushdie.

Ekman got the idea for Herrarna i skogen as early as the 1970s, when she started reading and thinking about the forest, collecting notes in a binder (Lenas 2007). However, she always seemed to get distracted by ideas for other books, even if she did not altogether abandon the thought of a nonfiction book about the forest. Thirty years after its conception, she finally wrote it. Most critics have viewed Herrarna $i$ skogen as a voluminous book of essays, which seems to confirm the author's own opinion of it. In an interview, Ekman has explained that she has been intrigued by the essay format for a long time. She especially stresses the freedom of the essayist to use language so variously, sometimes causing tension between the personal and the literary, the technical and the imaginative. "You can break up the structure, change the mood and the pace at will", she says (Paterson 2008b: 44). Again, as in the case of Lopate's book, Ekman seems to have sought for a form that could contain almost everything - regarding tone as well as material. As one critic has put it, Herrarna i skogen "combines passages of lucid prose-poetry with erudite, witty essays on history, literature, folklore, ecological biology, aspects of sociology and geo-economy, as well as punchy personal anecdotes, observations, and political polemics" (Paterson 2007: 76). The author herself has described the structure of the book as symbiotic with the forest itself: “'The paths are winding. They sometimes end blindly. You come across the unexpected, and the foul and dangerous, things you're tempted to 
avoid, but have to find your way through in the end.'” (Translated by Paterson 2008a: 41) As this quotation is part of the preface of Herrarna i skogen, it might probably be viewed as the author's instruction for how to read her book.

When the reader is confronted with such demanding and shifting texts as Waterfront or Herrarna i skogen, the sense of trust in the author might be crucial. In cases like these, the self-representation of the writer is among the major textual tools for gaining the reader's trust. Regarding the self-representation in the essay, it has been quite common to describe it by using the term persona, which refers to a mask or social role that is used by the author "to set him- or herself in the right posture towards particular subjects for a particular audience” (Cherry 1994: 91f). One of the chief functions of the persona in texts like Waterfront or Herrarna $i$ skogen seems to be to serve as a trustful reader's guide on an unpredictable journey - be it mental or geographical. This is an authorial role often put forward in studies of the essay, and it has been argued that honesty and reliability in the essayist are among the core values of the genre (Lopate 1995: xxv; Atkins 2008: 12, 59). Furthermore, the personae in Lopate's and Ekman's books may well be viewed as representatives of the belletristic amateurs typical of the essay tradition. While Lopate seems to be the witty, quite intimate flaneur of the big city (New York is his home town), Ekman, an outdoor woman equally learned but more detached, with her wellies on and her dog at her side, is at home walking, reading and thinking in the woods rather than in the city.

While Lopate advisedly has referred to himself as a generalist as opposed to the specialist, Ekman has rather emphasized the literary status of the essay and Herrarna i skogen belonging to literature (e.g. Lenas 2007). It seems that in Ekman's view, as long as your writing is acknowledged as literature, you can take liberties with materials and methods. She considers the essay an unbeatable form of literature, as it offers new knowledge to the reader, and combines it with a personal point of view and an eloquent style (Unge 2007: 98). Ekman's description might remind us of Horace's "utile dulci”, as her aim seems to be to delight as well as inform the reader.

In Ekman's view, the essay form obviously offers knowledge of something, which makes it adequate to ask what sort of knowledge this might be. Is it somehow related to the amateur stance in the essay tradition? Graham Good (1988; 1997) has addressed these issues, as he has stressed the essay's position outside of and in opposition to a system of specialization. He claims that the essay opposes the organising structures of academic knowledge and does not aim at a system. Rather, the essayist's observations are free - they do not "seek authority from tradition and doctrine" and they are often rooted in individual experience (Good 1988:4). Like many other essay theorists (e.g. Adorno 1958/1997), Good has tried to capture the character of the essay mainly by contrasting it with disciplinary expertise and its major genre - the academic article. While the discipline carefully distinguishes its area of investigation and defines its proper 
method, the essay "cultivates diversity"; it is provisional and personal, "thus nondisciplinary" (Good 1988: 6). While each individual contribution to the discipline has to take account of previous contributions on the topic (which is often carried out by quotes and footnotes), the essayist is free to look for subject matter anywhere, which might include making use of personal experience. As the essay's knowledge is "situated", its claim to truth is limited, it "is for here, for now, and for me" (ibid.: 23). The insights of the essay are thus non-transferable, they do not offer a theory or a method which can be applied to other objects, which makes the essay less useful from a disciplinary point of view (ibid.: 24).

As for the question of the learning of the essayist, the essay "is not in itself a 'learned' work in the sense of contributing to a common system of knowledge”, even though essayists frequently express their personal learning, often through quoting (ibid.: 6). However, the essayist's learning, his or her formal credentials or academic degrees (if any), might not be among the major sources of authority. As the essay "possesses neither the institutional legitimacy of a scientific treatise nor the cover of traditional generic conventions (lyric, epic, dramatic), authority is intimately tied to the author", writes Elizabeth Mittman (1993: 95). Likewise, Good (1988: 7; 1997: xx) has stressed that the essayist's authority is expressed chiefly through his or her personal experience and the personality as it is reflected in the style of writing.

How are we then to understand the authority of Herrarna i skogen in the light of the above statements? Might there be answers in the critical response to Ekman's work, and have critics made a point of the author's massive learning? First of all, it is likely that as Ekman is already acknowledged as a distinguished writer, this has given her authority in this case as well. Further, she is predominantly a writer of fiction, which is one of the most prestigious of literary forms today, while the essay is often described as ancillary or secondary (e.g. Obaldia 1995: 4; Good 1997: xxi; Atkins 2005: 11-25). It is probable that the public acknowledgement of Ekman as a writer has made it irrelevant that she is in this case expressing herself in a less prestigious genre. Besides, who could avoid being impressed when an author has been working on a book for thirty years? Herrarna i skogen is a life's work. Consequently, Swedish reviewers often seem to have felt overwhelmed but clearly and positively impressed while reading the book, but there are also some descriptions of exhaustion and feelings of intellectual inferiority (e.g. Lingebrandt 2007; Luther 2007). One reviewer (Kronqvist 2007) even asked herself who the supposed reader of Herrarna $i$ skogen might be - who was expected to be able to navigate through all these facts, references, historical figures and quotations piled up one after another? She pointed out that in small parts of the text, Ekman makes use of her own experiences and expresses her love for and concern about the forest, but that she does not seem to trust this personal commitment enough to be the centre and motivation for the book. Instead, Ekman covers herself with references to her 
learned gentlemen - she seems to feel obliged to account for everything, as if she was afraid that the personal perspective could not make room for her wideranging learning. This reviewer however discerned a slimmer, more pressing volume within Ekman's 550 pages - a pamphlet, an expression of love for the forest and an apology for the endangered species.

The observations made by this last reader could serve as background for a conclusion about where to place Herrarna i skogen in relation to the essay and more academic genres. Ekman's book shares the typical scope of the essay as she has not decided on any limits or restrictions for her subject matter. However, though Herrarna i skogen is not a contribution to a specialized discipline, Ekman seems to have taken into account almost every possible previous depiction of the forest that she has come across. What distinguishes Herrarna i skogen is that she has added on to her material for years and years. In this case, it has resulted in an aesthetics of exhaustion (rather than an aesthetics of impurity, as in Lopate's case). While Ekman is clearly not addressing a specialist audience in the disciplinary sense, Herrarna i skogen serves among other things as a display of the author's immense learning, and thus, it certainly demands an educated, attentive and above all persistent reader. It is likely that the public function of *Herrarna i skogen* has much in common with the communicative relation of the essay to the educated, though non-specialized, audience of the past (cf. Rohner 1966: 351, 372, 557; Haas 1969: 24, 80f.; France 2005: 35f.). Nevertheless, there are also major differences between Ekman's book and the personal essay, most favoured in the Anglo-American tradition, that strives for the ideal of "light learning” (Lopate 1995: xlii). The most salient one is that Ekman does not primarily seek authority by referring to her own experience - the voice in Herrarna i skogen is not so intimate and confidential as in the personal essay.

\section{The Essay Murder in the Library - a Debate on the State of the Essay in Sweden}

As can be seen above, Kerstin Ekman has maintained that the essay is a literary genre. Likewise, her shield against intrusion from the media and expectations of her to pronounce on matters of politics and morality has been to claim the autonomy of literature: “'I don't enter policy debates. I'm a writer'”, is a recurrent comment (e.g. Paterson 2008a: 42). When interviewers ask her if Herrarna $i$ skogen might not be perceived as a contribution to the debate on deforestation or environmental policy, Ekman persists in that her book is literature, not a pamphlet or an apology (Lenas 2007).

The status of the essay as a literary genre was also a starting point for a debate in one of the major Swedish newspapers, Dagens Nyheter, in 2003. The initiator was Nina Burton, essayist and poet, who started by expressing her concern for the essay being dispersed in Swedish libraries (Burton 2003a). As essays were not 
being located on a certain shelf, but were catalogued by subject matter and placed among works of nonfiction in general, one could get the impression that the essay was not viewed as belonging to literature. Just like the novel, Burton argued, the essay was a literary genre in its own right and it should therefore be placed by form and not by content. With a striking comparison, she stated that no one would ever think of sorting War and Peace under Military Science or Madame Bovary under Biography, while this constantly happened to essay books (2003c). In three witty, rhetorically effective articles, Burton further underlined her message by satirical metaphors and allusions to literature and mythology. She claimed that the dissemination of essays in the library was a matter of "murder" (which likely inspired the editorial headline "The cruel essay murder in the library", perhaps alluding to whodunits like Agatha Christie's The Body in the Library) (2003a). She also stressed the conformity of the classification system by comparing it to the iron bed of Procrustes where the mythological bandit amputated every limb that did not fit his bed (2003b). She even created an inverted Ten Commandments by stating that if the essay was not to be seen as belonging to literature, there would be an alarming change of the definition of the latter. Literature would then be, according to the standard Swedish classification system (SAB), not to be too serious, not to know too much on the matter in question, not to make use of facts, not to strive for the bigger picture, and not to express thoughts on a certain matter (2003a).

What was at stake in this debate, at least for its initiator, was not so much the principles of classification in general as the changing definition of literature. The physical location of essays in the library was given a symbolic function, but what Burton really wanted to discuss was something more abstract. Perhaps as a result of this, debaters representing different interests evidently talked at cross-purposes in the debate following Burton's first article. Librarians and representatives of the Swedish classification system (Berntson 2003, Fredén 2003, Myrstener 2003) explained the principles of classification and the advantages of sorting by subject matter, they gave advice on how to find your way through the library data-bases, or they seized the opportunity to lament on the recent decline of Swedish folklibraries (i.e. public libraries). On the opposite side, besides Burton, there were other writers and critics (Eriksson 2003, Thente 2003) who elaborated on her analysis of the relation of the essay to literature. According to writer and critic Ulf Eriksson,, the apparently low status of the essay in Sweden was culture-specific. He claimed that in other European countries like France, Spain, Italy, or Germany, the essay was without question a vital part of public life. In these countries, there were prestigious awards for essayistic writing and the essay could serve as an intermediary zone in society. Literary critic Jonas Thente did not hesitate to suggest that the weakening of the Swedish essay might be due to Swedish essayists themselves, as they were content to write belletristic articles. These articles in the guise of essays could easily be summarized or reduced to a single 
subject, and could therefore not be viewed as real essays, while an essay should be impossible to truly describe.

The above debaters are not the only ones who have pointed to the low status of the Swedish essay in the last few years. In a recent essay collection, the former permanent secretary of the Swedish Academy, essayist and critic Horace Engdahl (2009: 7f), has regretted the shrinking public space for essayistic writing in the last two decades. Engdahl himself was during the 1980s one of the major contributors to Kris, a Swedish learned journal introducing many of the central continental philosophers and thinkers of the time (e.g. Derrida, Barthes, Blanchot, Adorno, Benjamin, Lacan). In retrospect, Kris was often accused of adding fuel to the post-modern cultural climate of the 1980s, but it clearly also contributed to a renewed interest in theory in the university departments of literature in Sweden (Arping 2009: 545). Kris also favoured the critical essay as its chief form of expression and, as is apparent from Engdahl (2009: 7), the members sometimes expressed a wish that this type of criticism be viewed as a pursuit distinct from literature, but equally valuable. Engdahl however concludes that it is more difficult than ever to maintain such an ideal today, since the blogosphere has triumphed and the media no longer have room for reflective writing.

The tendency among Engdahl, Burton and other Swedish writers and critics to talk about a decline of the essay in public life in recent years, or to observe that the relation of the essay to literature is ambivalent, is neither unique for Sweden, nor is it new. Rather, these observations seem to have been omnipresent for a long time. For example, Ludwig Rohner (1966: 120) has noted that the low status of the essay in German culture was already apparent in the 1930s. A somewhat different but recurring example of later decades might be the debate, probably most clearly expressed in the United States, about the weak position of "creative nonfiction” in English studies (e.g. Hesse 2003). Even though creative nonfiction and similar concepts are much more wide ranging than the essay (e.g. Root 2003), many of the American advocates of the essay genre of later years have expressed themselves by referring to such labels, or speaking about creative nonfiction as the "fourth genre" (e.g. Klaus 1991; Root \& Steinberg 2007). There are however those who have remained sceptical of attempts to make the essay purely literary. In his introduction to genre theory, Alastair Fowler (1982: 5) concludes that the essay, along with genres like biography, dialogue and history, is "literature in potentia". This quite effective description of the essay's borderline position has been further commented on by Claire de Obaldia (1995: 16), who has stated that "the essay is, and [...] is not literature; or rather, the essay is not yet literature". The relation of the essay as a genre to literature is contingent, but this has not prevented particular essays and essayists making their way into a literary canon.

Despite the fact that essays are often viewed and treated ambivalently - as "literature in potentia" - whether in the United States, in Germany or in Sweden, one might still distinguish between essay traditions of different countries. While it 
is not possible to make a detailed comment on this matter here, some short points should however be made. As Kuisma Korhonen (1998:14) has noted, the Scandinavian essay has for a long time been associated with literary criticism, "sometimes in a pejorative sense: in academic circles the word 'essayistic' often refers to a loosely written tractate lacking proper documentation”. In addition, Göran Hägg (1978) has stressed that the tendency in Sweden to use the essay as a tool for literary criticism, or at least that literature has been the chief subject matter of essays, has been predominant since the turn of the last century. This is further emphasized in the article on the "Scandinavian Essay" in the Encyclopedia of the Essay, where the authors argue that the essay in individual Scandinavian countries has certain affinities: "The Danish essay might be called the subjective, personal essay; the Norwegian essay, the essay of national character; the Swedish essay, the literary essay.” (Mitchell \& Greene-Gantzberg 1997: 746.) The tendency to equate essayistic writing with criticism that seems to be predominant according to these examples should not be overstressed, however. Among the Swedish essayists discussed in this paper, Horace Engdahl is alone in expressing this view, while for example Nina Burton (2007) has argued against the essay being equal to criticism. Conversely, Burton as well as Ekman have maintained that the essay is a literary genre, whereas Engdahl (2009: 116f, 148) has rather made a distinction between the essay and literature.

In the above mentioned article from the Encyclopedia , the ancillary status of the essay in the Scandinavian countries is stressed as well:

In some literary histories the term "essay" is not even indexed. In others, the essay is generally treated as an author's secondary preoccupation; little effort is made to clarify the relationship between the essay and other genres. Although the essay is much discussed, it is relegated to the less important corners of secondary and university instruction. (Mitchell \& Greene-Gantzberg 1997: 746)

It seems that from these descriptions, the Swedish essay is far away from the continental tradition (France, Spain, Germany), where the essay has served as one of the major genres of intellectual writing during the post war-period (cf. Korhonen 1998: 13f). However, it is evident that Swedish writers like Horace Engdahl have expressed a conception of the essay that has much in common with the continental tradition, likewise that this tradition has probably had an influence on the Swedish discussion on the essay over the last few decades, not least in literary journals. It should be noted, however, that the essayistic writing of continental philosophers like Benjamin, Adorno, Weil, Cioran, Camus, Barthes often following the aphoristic style of Nietzsche - is a type of writing that is quite different from the informal, conversational style of the personal or familiar essay often favoured in the English speaking culture. The continental "essayism" has been described as a "subversive tool of skeptical probing" and as a "critique of ideology in a time when large, synthesizing theories and systems of philosophy are no longer trusted" (Lopate 2007: 390). According to Phillip Lopate, the view of essayistic writing as something serious and philosophical is only beginning to 
influence American essayists today, while the more intimate, chattering and friendly voice has long been preferred. In Sweden, however, essayists at least of later decades have often been reluctant to be too intimate with the reader. The eloquent, slightly detached, and very learned voice that we can distinguish among essayists like Horace Engdahl or Kerstin Ekman seems to be a recurring persona in the Swedish essay tradition. Whether this tells us something about the cultural climate of Sweden or not can of course not be established from these few examples, though it might be a suggestive hypothesis for a more wide ranging study of essayist personae in Sweden as compared to other countries.

\section{A Form for Expressing Ambivalence - Peter Nilson's “Solar Winds”}

Despite the above description of the Swedish essayist as being somewhat reserved, my last example, Peter Nilson, would seem at least a bit different, as his voice is more personal and venturesome than most Swedish essayists I have come across. However, he is, just like Kerstin Ekman in Herrarna i skogen, acting as a generalist with regard to his refusal to stay within disciplinary boundaries and in his desire for the larger picture. This makes him an adequate example of the amateurism that Said claimed to be a necessity in a professionalized world, in my view not least because Nilson favoured the essay as a form of communication.

Even though Nilson dreamed of being a writer at an early age, he was also inspired by Einstein and Darwin and eventually became an astronomer at Uppsala University. There, he compiled a widely acclaimed catalogue of galaxies and was made a senior lecturer in the mid 1970s. At this time though, he felt that his wide ranging interests could not be satisfied by doing scientific research (Nilson 1996). Accordingly, he abandoned his academic career for the more insecure path of the writer. Until his death in 1998, he wrote a number of novels and essay books which were often greatly inspired by scientific theories and ideas, but equally by philosophical, religious and mythical thought of the Western culture in general. Despite the evident eclecticism of Nilson's inspirational forces, his essays were often perceived as contributions to popular science. Perhaps the tendency to view Nilson as a popularizer was reinforced by his appearance in a famous Swedish radio show (Svar idag), where listeners would phone in to pose questions on different subjects to a panel of experts. Nilson was also elected member of the Royal Swedish Academy of Sciences in 1993.

In the early 1990s, Peter Nilson published three essay books of a similar character where he aimed at describing the scientific world view of our time and ourselves as inhabitants of the universe (Nilson 1993a: 225). The last of these books, Solvindar ("Solar Winds", 1993), is the one that will be in focus here. Just as in the case of Kerstin Ekman's Herrarna i skogen, Solvindar was nominated in the category of nonfiction for the August Prize in 1993, but neither of them 
received the prize.

To give an adequate and brief description of Solvindar is not easy. The essayistic writing of Peter Nilson seems to be a neverending search for the missing pieces in the big puzzle that is the world. In nine winding essays, Nilson hovers around recurring questions, often concerning fundamental conditions of human existence: How is human life possible? Are we alone in space? What are the boundaries for our knowledge of the universe? What exactly is the human soul? What would it be like to travel back in time and will we ever be able to do so? Of what concern is science to everyday life?

As there are hardly any simple answers to these questions, they rather serve as expressions of the disposition of the essayist. Nilson's persona is clearly ambivalent - he embodies the rational ethos of the scientist as well as the whimsies of the dreamer (Eldelin 2008: 249-252). Nilson's essays seem to be expressions of the self, thinking. In fact, they might even profess a Montaignian view of the essay. As has been pointed out by many, Montaigne did not use the word essai as a generic concept but as a methodological principle (referring to the verb essayer). As one of his many interpreters, R. Lane Kauffmann (1989: 224), has put it: “To essay is to experiment, to try out, to test - even one's own cognitive powers and limits.” Essaying, for Montaigne, was an ongoing process of trying out ideas and weighing his own experiences through writing (Rohner 1966: 66f.; Obaldia 1995: 29). Even if Nilson does not claim, like Montaigne, that his essays are foremost explorations of the self, he frequently confronts his own experiences with the peculiarities of human existence. What distinguishes Peter Nilson as an essayist is the intimate voice and the sometimes direct addresses to the reader, the recurring autobiographical references and a penchant for playfulness and fictive elements. Foremost, however, Nilson poses questions, to himself as well as to the reader. And rather than providing the reader with answers, as the questions that fascinate him often challenge the boundaries of thinking, it is the trying out and the probing that marks the core of Nilson's essays.

In Nilson's case, just as in Kerstin Ekman's or Phillip Lopate's, the value of freedom connected to the essay as form (cf. Klaus 1989: 160) allowed him to cross boundaries and confront ideas and topics from different areas in society. It was Peter Nilson's pronounced ambition to do so - he has expressed that the intention of his writing was to let the arts and the sciences reflect each other (Nilson 1993b: 248). In public life, he was often perceived as a reconciler of the two cultures that C.P. Snow (1959/1961) once pointed to and which were widely discussed in Sweden (Eldelin 2006). That Nilson often touched on matters that he had no first-hand knowledge of, as a generalist, was rarely considered a problem in public life. Rather, some critics viewed his learning as boundless, not only in his own field but in philosophy, religion and cultural history as well (e.g. Jacobson 1993; Anshelm 1994; Wallroth 1994). That Nilson appeared to be the 
very opposite of the specialist was met by reviewers with admiration and praise. However, these reviewers rarely claimed to be able to determine whether there might be errors among the massive heaps of facts that Nilson provided the reader with. As one reviewer noted, as Solvindar was a work of art and not solely of science, some minor errors would not affect the quality of the book (Kälvemark 1993). Nevertheless, Nilson himself does not seem to have been as anxious as Ekman or Burton to describe the essay as a purely literary form. Rather, he asserted that the ambition of his essay trilogy was to cross the boundaries of the science essay and literature (Nilson 1993b: 248). By literature in this case, it is likely that Nilson mainly referred to fiction, as there are recurring fictive elements in his essays, among them apparently fictional anecdotes but also a play with fictive or mythological identites (Eldelin 2008: 249-252).

Despite the playfulness and irony that mark the essayistic writing of Peter Nilson, it might be tempting to compare him with Phillip Lopate's expert essayists, writers like Stephen Jay Gould or Oliver Sacks, since Nilson shares their scientific background and was considered a popularizer of science in public life. Is it, in this case, the scientific training of the author that has given him the authority to speak, rather than the personal experience that is often put forward as ground for authority in the essay? From the reception of Peter Nilson's work, not least Solvindar, it is clear that critics have often perceived Nilson as keeping himself informed of what was going on at the research frontier in his own as well as in neighbouring fields. This is a recurring picture of the writer even twenty years after he quit his career as a scientist (Eldelin 2009: 83). It seems that the high social status of science as expert knowledge is passed on to the reception of Nilson's essays, even though he has also received praise for his literary style and for making readers feel as fellow travellers on a challenging intellectual journey (e.g. Gellerfelt 1993; Törnlund 1993; Wallroth 1994). As stated above, however, the persona in Nilson's writing is not acting as the convincing expert that one might perhaps expect, following Lopate's description. For Nilson, the essay rather becomes a form to hold his ambivalence; it allows him to constantly shift between different modes and to express his uncertainty (cf. Eldelin 2006: 287). Therefore, it might be more adequate to compare the essays of Nilson with the natural science writing of the American anthropologist and philosopher Loren Eiseley, as they both shared a sense of wonder at the marvels of the natural world which is expressed through their texts (cf. Nilson 1993b: 248, who has stated that Eiseley was an inspirational source for his essayistic writing). In Eiseley's perhaps most well-known book, The Immense Journey (1957), the evolutionary perspective of science shares the space with philosophical and religious contemplation, poetic nature descriptions and autobiographical anecdotes. Apart from the apparent compositional similarities between the writings of Nilson and Eiseley, they both used the essay form to express a personal and imaginative response to scientific facts and to a scientific view of the world. As Andrew J. Angyal (1993: 61) has 
noted, Eiseley "found it increasingly difficult to reconcile his 'personal universe' with the rational universe of science”, where everything was reduced to measurable facts. A similar disillusion with regards to the rationalism of science, though perhaps not as pointed as Eiseley's, could be found in Peter Nilson and in his choice to be a writer rather than moving on as a scientist. Nilson seems to have shared with Eiseley a certain intellectual temperament that sought connections between facts and imagination. In Eiseley's case, it has been compared to that of the Victorian scientist, who was not “intimidated by the 'two cultures' division or the fear of bridging disciplines” (ibid. 1993: 64).

\section{The Essayist and the Growing Tension Between Amateurism and Professionalism}

In intellectual history, the growing tension between amateurism and professionalism in Western countries has often been traced back to the nineteenth century, the very time of Victorian scientists like Darwin. Before that, scientists and humanists did not form exclusive university circles separate from those of other educated people, and the learned amateur or dilettante was welcome to participate in scholarly and scientific work. Gradually during the nineteenth century, however, rules were formulated and methods and fundamental principles were established that made it increasingly difficult for non-academics to be recognized by scientists and scholars. Along with a new social and institutional organisation of science, new social identities for research practitioners emerged as well: the ideal of the specialist scholar eventually replaced the broad-ranging generalist (Torstendahl 1993; Wittrock 1993). As a result of this development, the amateur culture seemed more and more outdated at the turn of the century. This was even more the case after World War I, when new socialist intellectual groups referred to themselves and their work as objective, scientific and specialized (cf. Mauriello 2001). Nevertheless, it seems to have been possible, even after that time, to combine scholarship with being a generalist with a public position. Not surprisingly however, the scholar who wanted to communicate with a wider audience through the medium of the essay or through public lectures was met with increasing challenges in a society of growing specialization. One example from the Swedish-speaking culture could serve as an illustration. As Thomas Ek (2003: 18) has pointed out, the chief expression of the Finno-Swedish aesthetician, philosopher and writer Hans Ruin was the essay in its many forms; he wrote autobiographical, philosophical, political as well as literary essays. Ruin rejected a professorship in Åbo and emigrated to Sweden in the late 1940s. Besides being appointed senior lecturer in aesthetics at Lund University, he was known as a popular speaker and lecturer, not least on the radio, where he could express his wide sphere of interests, ranging from philosophy and psychology to aesthetics and literary history. Ek notices that Ruin, at least periodically, considered himself 
an outsider in the academic world. In his diary notes from the 1960s, he expresses a growing disillusion over not getting the academic acknowledgement he expected, and blames it on himself being too versatile. In his own eyes, his penchant for bridging genres and disciplines became a weakness. He was met with the "tyranny of genres", which neither promoted his academic career, nor gave him a place in literary history (ibid.: 123-126). The borderline position so typical for essayists and for the essay genre could certainly be traced in the authorship of Hans Ruin.

Despite the proceeding specialization and professionalization that seems to have bothered Ruin in the 1960s, and which might seem even more pressing half a century later, Edward Said was persistent in his talk of the necessity of intellectuals adopting an amateur stance in public life to be able to look for the larger picture, to challenge conformity and to raise moral issues. As amateurism, for Said (1994: 54f, 61), was not an occupation but an attitude, he considered it to be possible to combine with being an academic. Said did not primarily, like other debaters of the time, blame universities for the decline in intellectual life. Here, he argued chiefly against Russell Jacoby (1987: 141), who had claimed that professionalization at universities had led to a "privatization” among intellectuals and to a "withdrawal of intellectual energy from a larger domain to a narrower discipline”. However, it might be adequate to remain, along with Jacoby, a bit sceptical about the possibility of an attitude of amateurism residing within academia, not least today, when university managements as well as single scholars and scientists increasingly seem forced to rely on bibliometrics, citation analysis, rankings and high impact factors as the chief measurements of academic quality. One might ask if devotion is even compatible with the bibliometric system?

The examples that have been discussed in this paper confirm that the relation of the essay and the essayist to academia and institutional discourse remains ambivalent, just as it has been for a long time, despite the common ground of the essay and the emerging modern science in late sixteenth century Europe (Hall 1989; cf. Good 1997: xx). This ambivalence will probably be even more accentuated the more we rely on bibliometrics in academia. Among the Swedish essayists that have been put forward here, apart from Ruin, none has remained a scholar or scientist at the university even though several of them have received high academic degrees and might therefore be considered professionals of some kind (Nina Burton and Horace Engdahl both hold PhD's in literature, Peter Nilson a $\mathrm{PhD}$ in astronomy). Irrespective of these writers having deliberately chosen to reside outside of academia or not, it is doubtful that they would have been able to fully express and develop their penchant for essayistic inquiry and experimental writing within modern academia. Nevertheless, all of them have or have had affiliations with institutions or academies that at least historically could serve as competitors with the universities with regards to learning (cf. Wittrock 1993). 
Engdahl and Ekman are members of The Swedish Academy, Nilson was a member of The Royal Swedish Academy of Sciences and Burton is an elected member of Samfundet de nio, another Swedish prize-awarding and learned literary society. These affiliations, along with the reception of their essayistic work, confirm that these writers have adopted or been ascribed to public roles that clearly resemble the learned amateur essayist or man of letters of the past, even though they have not explicitly or deliberately referred to themselves as amateurs (perhaps this is due to the contemporary connotations of amateur being somewhat more disparaging than positive).

However, in the essayistic writing of these authors and in their view of the public function of the essay, one might also find prevailing traces of originally romantic ideas of the autonomy of literature and the independence of the artist. The tendency to describe the essay as belonging to literature or to defend oneself from public debate that can be seen in some of these examples suggests that there is a certain reluctance among modern essayists to act as the "amateurish conscience" that Said (1994: 62) was asking for. The scepticism of today's essayists to claim moral authority also distinguishes them from many of the learned amateurs of the past, not least in the British tradition, where morality and manners were among the chief subjects of periodical essayists like Joseph Addison, Richard Steele, or Samuel Johnson (cf. France 2005: 35f). However, it could also be that as essayists have excused themselves "from the job of pontificating to the public" (Lopate 2007:391), they have remained true to the ethos of the essay tradition, which since Montaigne has been marked by scepticism and by the rejection of all kinds of totalizing modes of thinking (cf. Adorno 1958/1997). Still, it cannot be denied that essay books like Kerstin Ekman's Herrarna i skogen, Peter Nilson's Solvindar, or other similar essayistic works, have often been acclaimed in public for being syntheses of some kind, however fragmentary, maps of meaning or graspings at the larger picture driven by a devotion for the subject. In a time when we are overwhelmed by disruptive information and increasingly tend to rely on experts of all kinds, the discourse of the essayist, which might still be adequately described as "an amateur's raid in a world of specialists” (Sanders 2007: 417), seems more essential than ever.

Emma Eldelin holds a PhD in Communication Studies and wrote her dissertation on how the concept of the two cultures was interpreted and made use of in public debate in Sweden. At present, she is a teacher of literature at the Department of Culture and Communication at Linköping University. Among her major research interests are the state of the essay in late modernity and the shifting public roles of essayists. E-mail: emma.eldelin@liu.se 
The writing of this paper was made possible through fundings from The Royal Swedish Academy of Sciences and the Department of Culture and Communication at Linköping University.

\section{References}

Adorno, Theodor (1958/1997): “Der Essay als Form”, Gesammelte Schriften, 11: Noten zur Literatur, Frankfurt am Main: Suhrkamp, 933.

Angyal, Andrew J. (1993): “Loren Eiseley’s Immense Journey: The Making of a Literary Naturalist”, Murdo William McRae (ed.), The Literature of Science: Perspectives on Popular Scientific Writing, Athens: University of Georgia Press, 54-72.

Anshelm, Gunnar (1994): “Kosmiska resor”, Skånska Dagbladet, January 2nd.

Arping, Åsa (2009): “Kulturtidskriften Kris och den 'postmoderna’ vändningen”, Bernt Olsson et al. (eds), Litteraturens historia i Sverige, 5th edition, Stockholm: Norstedts, p 545.

Atkins, G. Douglas (2005): Tracing the Essay: Through Experience to Truth, Athens: The University of Georgia Press.

— (2008): Reading Essays: An Invitation, Athens: The University of Georgia Press.

Berntson, Göran (2003): “Inget essämord”, Dagens Nyheter, May 10th.

Boetcher Joeres, Ruth-Ellen \& Elizabeth Mittman (eds) (1993): The Politics of the Essay: Feminist Perspectives, Bloomington: Indiana University Press.

Burton, Nina (2003a): “Det grymma essämordet i biblioteket”, Dagens Nyheter, May 7th.

— (2003b): “Utan egen plats är essän hemlös”, Dagens Nyheter, May 14th.

- (2003c): “Om definitionen av skönlitteratur”, Dagens Nyheter, May 28th.

- (2007): "Essävandring”, Författaren, 4/5, 8-10.

Carey, John (1992): The Intellectuals and the Masses: Pride and Prejudice among the Literary Intelligentsia, 1880-1939, London: Faber.

Cherry, Roger D. (1994): "Ethos versus Persona: Self-Representation in Written Discourse”, Peter Elbow (ed.), Landmark Essays on Voice and Writing, Davis: Hermagoras Press, 85-105.

Ek, Thomas (2003), En människas uttryck: Studier i Hans Ruins självbiografiska essäistik, Helsingfors: Svenska litteratursällskapet i Finland.

Ekman, Kerstin (2007), Herrarna i skogen, Stockholm: Bonnier.

Eldelin, Emma (2006): “De två kulturerna” flyttar hemifrån: C. P. Snows begrepp i svensk idédebatt 1959-2005, Stockholm: Carlssons.

— (2008): “Vid tänkandets gränser: Om Peter Nilsons essäistik”, Samlaren: Tidskrift för svensk litteraturvetenskaplig forskning, 129, 239-269.

_ (2009): "Essäisten som generalist: Författarroller och offentlig auktoritet hos tre samtida essäister”, Tidskrift för litteraturvetenskap, 39:3-4, 81-92.

Engdahl, Horace (2009): Ärret efter drömmen: Essäer och artiklar, Stockholm: Bonnier.

Eriksson, Ulf (2003): “Essän är litteraturens själ”, Dagens Nyheter, May 17th.

Fowler, Alastair (1982): Kinds of Literature: An Introduction to the Theory of Genres and Modes, Oxford: Clarendon Press.

France, Peter (2005): "British and French Traditions of the Essay”, Charles Forsdick \& Andrew Stafford (eds), The Modern Essay in French: Movement, Instability, Performance, Frankfurt am Main: Peter Lang.

Fredén, Krister (2003): “Svårt att dela upprördheten”, Dagens Nyheter, May 21st.

Gellerfelt, Mats (1993): “Astronom med fötterna på jorden”, Svenska Dagbladet, August 30th.

Good, Graham (1988): The Observing Self: Rediscovering the Essay, London: Routledge.

(1997): “Introduction”, Tracy Chevalier (ed): Encyclopedia of the Essay, London: Fitzroy Dearborn, xix-xxi.

Gross, John (1969): The Rise and Fall of the Man of Letters: Aspects of English Literary Life since 1800, London: Weidenfeld and Nicholson.

Haas, Gerhard (1969): Essay, Stuttgart: J.B. Metzlersche Verlagsbuchhandlung.

Habermas, Jürgen (1962/1989): The Structural Transformation of the Public Sphere: An Inquiry into a Category of Bourgeois Society, Cambridge: Polity Press. 
Hall, Michael J. (1989): “The Emergence of the Essay and the Idea of Discovery”, Alexander J. Butrym (ed.), Essays on the Essay: Redefining the Genre, Athens: University of Georgia Press, 73-91.

Hesse, Douglas (2003): “The Place of Creative Nonfiction”, College English, 65:3, 237-241.

Huxley, Aldous (1960): Collected Essays, London: Chatto \& Windus.

Hägg, Göran (1978): Övertalning och underhållning: Den svenska essäistiken 1890-1930, Stockholm: Wahlström \& Widstrand.

Jacobson, Magnus (1993): “Finns universum utan oss?”, Östgöta Correspondenten, August 30th.

Jacoby, Russell (1987): The Last Intellectuals: American Culture in the Age of Academe, New York: Basic Books.

Jonsson, Stefan (2007): “Nya stigar i kulturhistorien”, Dagens Nyheter, March 20th.

Kauffmann, R. Lane (1989): “The Skewed Path: Essaying as Unmethodical Method”, Alexander J. Butrym (ed.), Essays on the Essay: Redefining the Genre, Athens: University of Georgia Press, 221-240.

Klaus, Carl H (1989): “Essayists on the Essay”, Chris Anderson (ed.), Literary Nonfiction: Theory, Criticism, Pedagogy, Carbondale: Southern Illinois University Press, 155-175.

(1991): "Elements of the Essay", Robert Scholes et. al. (eds): Elements of Literature: Essay, Fiction, Poetry, Drama, Film, 4th ed., New York: Oxford University Press, 3-8.

Korhonen, Kuisma (1998): Essaying Friendship: Friendship as a Figure for the Author-Reader Relationship in Essayistic Textuality, from Plato to Derrida, Helsinki: Yliopistopaino.

Kronqvist, Alexandra (2007): “Vilse i snårskogen”, Sydsvenska Dagbladet, March 20th.

Kälvemark, Torsten (1993): "Spelar det någon roll i universum att vår själ finns?”, Aftonbladet, August 30th.

Lenas, Sverker (2007): “Damen i skogen”, Dagens Nyheter, March 18th.

Lingebrandt, Ann (2007): "I Ekmans bokskog”, Helsingborgs Dagblad, March 20th.

Lopate, Phillip (1995): "Introduction”, Phillip Lopate (ed): The Art of the Personal Essay: An Anthology from the Classical Era to the Present, New York: Anchor Books, xxiii-liv. (2004): Waterfront: A Walk Around Manhattan, New York: Anchor Books.

- (2007): "What Happened to the Personal Essay?", Robert L. Root \& Michael Steinberg (eds): The Fourth Genre: Contemporary Writers of/on Creative Nonfiction, New York: Pearson Longman, 384-391.

Luther, Annika (2007): "Medvarelser i skogsdjupet”, Hufvudstadsbladet, August 19th.

Mauriello, Christopher E. (2001): “The Strange Death of the Public Intellectual: Liberal Intellectual Identity and the 'Field of Cultural Production' in England, 1880-1920”, Journal of Victorian Culture, 6:1, 1-26.

Mitchell, P. M. \& Vivian Greene-Gantzberg (1997): “Scandinavian Essay”, Tracy Chevalier (ed): Encyclopedia of the Essay, London: Fitzroy Dearborn, 743-747.

Mittman, Elizabeth (1993): “Christa Wolf's Signature in and on the Essay: Woman, Science, and Authority”, Boetcher Joeres, Ruth-Ellen \& Elizabeth Mittman (eds) (1993): The Politics of the Essay: Feminist Perspectives, Bloomington: Indiana University Press, 95-112.

Myrstener, Mats (2003): “Essäns svåra kamp”, Dagens Nyheter, May 21st.

Nilson, Peter (1993a): Solvindar: En bok om rymd och människor, Stockholm: Norstedt.

_ (1993b): “Nilson, Peter”, Bo Heurling (ed.), Författaren själv: Ett biografiskt lexikon om och av 1189 samtida svenska författare, Höganäs: Wiken, p 248.

— (1996): "Berättandets glädje och himlarnas oändlighet”, Marianne Arhne et al., Hur jag blev författare, Stockholm: Norstedt, 127-137.

Obaldia, Claire de (1995): The Essayistic Spirit: Literature, Modern Criticism, and the Essay, Oxford: Clarendon Press.

Olsson, Bernt, Ingemar Algulin et al. (eds.) (2009): Litteraturens historia i Sverige, 5th edition, Stockholm: Norstedts.

Paterson, Anna (2007): review of Kerstin Ekman's Herrarna i skogen, World Literature Today, 81:6, 76-77.

- (2008a): “Landscapes Remembered: Kerstin Ekman and Nature”, World Literature Today, 82:4, 40-42. 
(2008b): "Mistress of the Forest: An Interview with Kerstin Ekman”, World Literature Today, 82:4, 43-46.

Rohner, Ludwig (1966): Der deutsche Essay: Materialien zur Geschichte und Ästhetik einer literarischen Gattung, Neuwied: Luchterhand.

Root, Robert L. (2003): “Naming Nonfiction (A Polyptych)”, College English, 65:3, 242-256.

Root, Robert L. \& Michael Steinberg (eds) (2007): The Fourth Genre: Contemporary Writers of/on Creative Nonfiction, New York: Pearson Longman.

Said, Edward (1994): Representations of the Intellectual: The 1993 Reith Lectures, London: Vintage.

Sanders, Scott Russell (2007): “The Singular First Person”, Robert L. Root \& Michael Steinberg (eds): The Fourth Genre: Contemporary Writers of/on Creative Nonfiction, New York: Pearson Longman, 416-424.

Snow, C. P. (1959/1961): The Two Cultures and the Scientific Revolution, Cambridge: The University Press.

Stebbins, Robert A. (1992): Amateurs, Professionals and Serious Leisure, Montreal: McGillQueen's University Press.

Taylor, Anita Darcel (2006): “Interview with Phillip Lopate”, Fourth Genre: Explorations in Nonfiction, 8:1, 125-137.

Thente, Jonas (2003): “En essä ska vara omöjlig att beskriva”, Dagens Nyheter, May 21st.

Torstendahl, Rolf (1993): "The Transformation of Professional Education in the Nineteenth Century”, Sheldon Rothblatt \& Björn Wittrock (eds), The European and American University since 1800: Historical and Sociological Essays, Cambridge: Cambridge University Press.

Törnlund, Niklas (1993): “Den osannolika jorden”, Sydsvenska Dagbladet, August 30th.

Unge, Ingemar (2007): “Svar på nummer 13: Bland tomtar och troll”, Tidningen Vi, March, 98.

Wallroth, Per (1994): Review of Peter Nilson’s Solvindar, Bonniers Litterära Magasin, 63:4, 60.

Wittrock, Björn (1993): “The Modern University: The Three Transformations”, Sheldon Rothblatt \& Björn Wittrock (eds), The European and American University since 1800: Historical and Sociological Essays, Cambridge: Cambridge University Press. 